\title{
Problems and Countermeasures of Agricultural and Rural Development in Africa
}

\author{
Manana Batapa Escoteresa \\ Central South University, Changsha, China \\ Email:2749369751@qq.com
}

How to cite this paper: Escoteresa, M. B. (2022). Problems and Countermeasures of Agricultural and Rural Development in Africa. Open Journal of Business and Management, 10, 643-653.

https://doi.org/10.4236/ojbm.2022.102036

Received: January 15, 2022

Accepted: March 6, 2022

Published: March 9, 2022

Copyright (C) 2022 by author(s) and Scientific Research Publishing Inc. This work is licensed under the Creative Commons Attribution International License (CC BY 4.0).

http://creativecommons.org/licenses/by/4.0/

(c) (i) Open Access

\begin{abstract}
The economic development in Africa is relatively slow. By promoting the development of rural areas and agriculture, it can effectively drive the local economic development speed. The development of agriculture and rural areas needs to improve efficiency by promoting industrial upgrading, so governments in Africa should promote industrial upgrading through scientific methods, use machinery production to improve the efficiency of agricultural development, and improve the quality of development in rural areas. This paper expounds on the problems and countermeasures in the development of agriculture and rural areas in Africa through qualitative analysis. First, the current situation of agricultural and rural development in Africa is analyzed through three parts: the development of African agricultural trade import and export, the development of agricultural added value in Africa, and the environmental development of rural areas in Africa. Analyze and explain. Then, the problems existing in the development of agriculture and rural areas in Africa are expounded in three parts: the relatively slow development of agricultural import and export trade volume, the relatively lagging overall economic development, and the low speed of urbanization; low, the speed of industrial transformation is not fast enough, and the government's policies are not scientific enough. The three parts are the reasons for the problems of agricultural and rural development in Africa. Finally, it proposes targeted policy recommendations for agricultural and rural development in Africa by promoting the proportion of agricultural mechanization production, promoting the acceleration of industrial transformation, and employing think tanks to use scientific macroeconomic development policies.
\end{abstract}

\section{Keywords}

Africa, Rural Development, Agricultural Development 


\section{Introduction}

The per capita GDP of Africa in 2020 is US\$1499, and the economic development of regional countries is under great downward pressure. The per capita GDP of the African region has grown from a high of \$1894 in 2014 to only \$1499 in 2020 after nearly six years of development. Therefore, the economic development of the African region needs certain policy stimulus to enhance the vitality of economic development. In 2020, the agricultural added value in Africa will account for $17.473 \%$ of the total economic growth, and promoting agricultural and rural development is still an important task ${ }^{1}$.

Only by continuously promoting rural industries can promote economic development. At present, the more common business organization model in rural Africa is the villager self-governance model under the leadership of the regional government. Every village in Africa has a local government responsible for management, and for rural areas, the local government implements the management role. The stable development of the village is guaranteed through the management of the government, but the inability to get rid of poverty is the most difficult problem. At present, the rural management model in Africa takes the lead in the development of local advantageous industries through the government, and drives the improvement of villagers' economy and income through the development of advantageous industries. This in turn promotes the continuous development of the local business organization model.

The choice of the rural management organization model in Africa can learn from China's rural management organization model, which can effectively promote the economic development of Africa. Rural issues are the core issues in Africa. Only by learning from the excellent rural management and organization models of China and other countries can we better improve the rural management and organization models and improve the economic development trend of Africa.

Scholars in many countries have conducted in-depth research on rural management and organization models, and rural development in Africa is an important topic, so many scholars put forward suggestions for rural development by studying rural organizational models. For example, Valipour (2015) and Schut et al. (2015) pointed out that the agricultural and rural development in Africa should learn from China's development model and drive local economic development through the development of advantageous industries. In the process of economic development, rural development can effectively drive the overall development of the overall economy, which plays a central role in the economic development of Africa.

\section{Literature Review}

The research of Valipour (2015) believes that China's rural governance is effective, and China's rural governance is developed through the leadership of the ${ }^{1}$ World Bank: https://data.worldbank.org.cn/indicator/NY.GDP.PCAP.CD?locations=ZG 
party committee and the form of villager self-governance. China's population base is large, and it is difficult for all people to get rid of poverty. However, under the leadership of the village party committee, economic development is driven by industrial development, thereby promoting rural villagers to get out of poverty. This is a milestone event for China's development. Schut et al. (2015) believes that the economic development of rural Africa needs the blessing of local advantageous industries, and rural hollowing has become an inevitable problem in the development of African cities. Only by improving the level of economic development and income in rural areas through industrial development can better attract rural laborers return to the countryside from the cities. Davis et al. (2017) pointed out that rural areas in Africa are basically in a state of self-government. Many rural laborers enter the cities for development, and more old people and children stay in the countryside. This is a typical characteristic of rural development in China.

Dawson et al.'s (2015) study believes that the Chinese government has deep experience in the field of rural governance. In the process of economic development, China's rural areas can effectively develop industries and produce agricultural and sideline products through the convenience of the Internet. This form of governance can be better. Take advantage of the advantages of rural areas to develop the economy. Nagler and Naudé's (2017) study pointed out that China's rural areas have certain disadvantages due to the serious hollowing out. However, there are party members' activity centers in rural China, and using the power of local party members can better lead the rural areas to become rich. The village chiefs and village party secretaries in different regions are all appointed by higher-level party committees, so China's party committees have direct responsibility for local development. The party committee has certain experience in the governance and development of rural areas, so it has become an important political achievement to use local advantageous industries to develop the economy. Therefore, the development of China's rural areas is relatively rapid.

Iwelunmor et al.'s (2016) research believes that there is a large space for the development of rural grassroots autonomy in Africa, and grassroots autonomy can effectively promote the construction of a democratic system in rural Africa. Rural development in Africa is relatively rapid, which is the result of policies that can reach the lowest level. Grassroots autonomy in Africa means that the leaders of the party committees of villages and towns mainly come from local villages and towns, and at the same time can effectively lead the villagers to get rich together, which has a positive effect on the development of villages and towns in Africa. Boahene (2015) pointed out that the role of villages and towns in economic development in Africa is high, and the rural population in Africa is huge. Only through better villager autonomy can the enthusiasm of rural areas be stimulated and the vitality of rural development be improved. According to Carter et al.'s (2016) research, villagers' grassroots self-governance is also self-government to a certain extent, self-governance under the leadership of the legal system and 
the party committee. This self-governance model can better drive African villagers to gain higher enthusiasm, and gradually build local advantageous industries to increase the overall income of the villagers.

\section{Status Quo of Agricultural and Rural Development in Africa}

\subsection{Development of African Agricultural Trade Import and Export}

Agricultural and rural development in Africa is mainly driven by crop products, so the development of African agriculture can be better explored through the import and export trade volume of agricultural products. The import and export trade of African agriculture can drive the agricultural development in Africa, and at the same time, it can effectively promote the development of foreign trade industry in Africa and improve the overall development vitality of agriculture. The development of the import and export trade of agricultural products in Africa from 2006 to 2020 is shown in Table 1 below.

Table 1. Development of African agricultural products import and export trade from 2006 to 2020.

\begin{tabular}{|c|c|c|c|}
\hline Year & $\begin{array}{l}\text { African agricultural } \\
\text { import trade volume } \\
\text { (billion US dollars) }\end{array}$ & $\begin{array}{l}\text { Africa's agricultural } \\
\text { export trade volume } \\
\text { (billion US dollars) }\end{array}$ & $\begin{array}{l}\text { The total import and } \\
\text { export trade of African } \\
\text { agricultural products } \\
\text { (billion US dollars) }\end{array}$ \\
\hline 2006 & 79.26 & 45.89 & 125.15 \\
\hline 2007 & 114.13 & 55.87 & 170.01 \\
\hline 2008 & 97.71 & 67.81 & 165.52 \\
\hline 2009 & 81.14 & 58.04 & 139.18 \\
\hline 2010 & 98.10 & 68.38 & 166.48 \\
\hline 2011 & 142.00 & 88.03 & 230.03 \\
\hline 2012 & 138.65 & 80.12 & 218.78 \\
\hline 2013 & 112.48 & 84.01 & 196.49 \\
\hline 2014 & 114.51 & 83.01 & 197.52 \\
\hline 2015 & 97.15 & 69.80 & 166.95 \\
\hline 2016 & 105.36 & 62.32 & 167.67 \\
\hline 2017 & 122.07 & 66.89 & 188.96 \\
\hline 2018 & 126.19 & 74.08 & 200.27 \\
\hline 2019 & 118.91 & 75.62 & 194.53 \\
\hline 2020 & 107.80 & 62.89 & 170.69 \\
\hline
\end{tabular}

Data source: UNCTAD. 
It can be seen from above Table 1 that the import trade of agricultural products in Africa has grown from US\$7.926 billion in 2006 to US\$10.780 billion in 2020 after nearly 14 years of development, with a small growth rate. At the same time, it can be seen that Africa's agricultural export trade volume has grown from US $\$ 4.589$ billion in 2006 to US\$6.289 billion in 2020 after nearly 14 years of development, an increase of nearly $37.05 \%$. From the perspective of the total import and export trade of agricultural products, the African region has grown from US $\$ 12.515$ billion in 2006 to US $\$ 170.69$ in 2020 after nearly 14 years of development. Overall, the growth trend of the total import and export trade of agricultural products in Africa exists, but the growth rate is relatively small.

\subsection{The Development of Agricultural Added Value in Africa}

The added value of agricultural production in Africa can reflect the agricultural development in Africa. At the same time, since the African agriculture in the sub-Saharan region is more representative of the agricultural development of the African black population, this paper regards the agricultural added value in sub-Saharan Africa as an important factor are analyzed. The development of agricultural industry in sub-Saharan Africa from 2006 to 2020 is shown in Table 2 below.

Table 2. Agricultural industry development in sub-Saharan Africa from 2006 to 2020.

\begin{tabular}{|c|c|c|}
\hline Year & $\begin{array}{c}\text { Agricultural value added in } \\
\text { sub-Saharan Africa (US\$ billion) }\end{array}$ & $\begin{array}{l}\text { Agricultural value added as a percentage } \\
\text { of GDP in sub-Saharan Africa (\%) }\end{array}$ \\
\hline 2006 & 148.56 & 18.28 \\
\hline 2007 & 177.87 & 18.25 \\
\hline 2008 & 219.27 & 18.74 \\
\hline 2009 & 211.51 & 19.20 \\
\hline 2010 & 226.17 & 17.90 \\
\hline 2011 & 237.13 & 16.94 \\
\hline 2012 & 256.23 & 17.15 \\
\hline 2013 & 272.75 & 16.35 \\
\hline 2014 & 287.44 & 16.24 \\
\hline 2015 & 274.09 & 16.45 \\
\hline 2016 & 257.29 & 16.39 \\
\hline 2017 & 265.83 & 16.35 \\
\hline 2018 & 276.69 & 16.14 \\
\hline 2019 & 295.22 & 16.09 \\
\hline 2020 & 315.59 & 17.47 \\
\hline
\end{tabular}

Data source: World Bank. 
It can be seen from above Table 2 that the agricultural added value in sub-Saharan Africa has grown from 148.56 billion in 2006 to 315.59 billion in 2020 after nearly 14 years of development. Therefore, the agricultural added value in sub-Saharan Africa has a large fluctuation service. The growth trend is good. At the same time, it can be found that the ratio of agricultural added value to GDP in sub-Saharan Africa has increased from 18.28\% in 2006 to $17.47 \%$ in 2020 after nearly 14 years of development, and the overall change is small.

\subsection{Environmental Development in Rural Areas in Africa}

Rural development in the African region can be reflected in sub-Saharan Africa's GDP per capita and the ratio of rural population to total population. GDP per capita can effectively reflect the per capita economic development of sub-Saharan regions, which can effectively represent the local economic development and the real development environment of rural areas. Then the proportion of the population in rural areas to the total population can reflect the local urbanization process, but also reflect the economic development. The development of agricultural industry in sub-Saharan Africa from 2006 to 2020 is shown in Table 3 below.

From Table 3, we can see that the per capita GDP in sub-Saharan Africa has grown from US\$1241.55 in 2006 to US\$1499.41 in 2020 after nearly 14 years of development. Therefore, the overall economic development per capita in sub-Saharan Africa is relatively backward. Economic development is in a

Table 3. Agricultural industry development in sub-Saharan Africa from 2006 to 2020.

\begin{tabular}{ccc}
\hline Year & $\begin{array}{c}\text { GDP per capita in } \\
\text { sub-Saharan Africa (US\$) }\end{array}$ & \multicolumn{2}{c}{$\begin{array}{c}\text { Sub-Saharan rural population as a } \\
\text { percentage of total population }(\%)\end{array}$} \\
\hline 2006 & 1241.55 & 65.96 \\
2007 & 1400.35 & 65.54 \\
2008 & 1548.34 & 65.03 \\
2009 & 1441.29 & 64.52 \\
2010 & 1654.85 & 64.00 \\
2011 & 1806.61 & 63.48 \\
2012 & 1827.61 & 62.96 \\
2013 & 1892.12 & 62.45 \\
2014 & 1894.03 & 61.93 \\
2015 & 1687.04 & 61.41 \\
2016 & 1528.14 & 60.88 \\
2017 & 1588.32 & 60.36 \\
2018 & 1626.06 & 59.82 \\
2019 & 1628.74 & 59.29 \\
2020 & 1499.41 & 58.75 \\
\hline
\end{tabular}

Data source: World Bank. 
relatively slow process, which has a certain impact on local rural development. At the same time, it can be seen that the ratio of rural population to the total population in sub-Saharan Africa has increased from 65.96\% in 2006 to $58.75 \%$ in 2020 after nearly 14 years of development. In the past 14 years, the proportion of rural population in Africa has declined to a certain extent, and the process of urbanization in Africa is slowly promoting, which also has a certain role in promoting the economic development of rural areas.

\section{Problems and Causes of Agricultural and Rural Development in Africa}

\subsection{Problems Existing in Agricultural and Rural Development in Africa}

\subsubsection{The Development of Agricultural Import and Export Trade Volume Is Relatively Slow}

The development of agriculture and export trade in Africa is relatively slow, which cannot effectively increase the income of local residents. Africa's agricultural development, as an important local supporting industry, should maintain a high development speed, so as to provide capital for industrial upgrading. Through agricultural import and export trade, the speed of agricultural development can be effectively increased, and the income of agricultural practitioners can be increased at the same time. Therefore, local agricultural products should continue to increase the speed of import and export trade, and at the same time pay more attention to the export trade of agricultural products, and increase the vitality of agricultural development through the increase of net exports of agricultural products.

\subsubsection{The Overall Economic Development Is Relatively Lagging behind} The African region has a relatively low GDP per capita and a slower pace of development. This is probably due to the use of primitive methods for local agricultural development. With the advancement of science and technology, the development of agricultural science and technology can help agricultural development to be more efficient. Industrial upgrading in Africa is relatively slow. Through industrial upgrading, the development of the agricultural industry can be better served, which has a positive effect on agricultural production in Africa.

\subsubsection{The Development Speed of Urbanization Is Low}

In 2020, the proportion of urban population in Africa to the total population is 41.252\%, compared with $60.698 \%$ in East Asia and the Pacific, $72.615 \%$ in Europe and East Asia, and $82.553 \%$ in North America ${ }^{2}$. Local economic development also has a certain impact. The development of urbanization is an important step in the industrial process. Since most African countries have not undergone industrialization, a large number of people can be pushed into cities through urbanization, and then the capital and industrial industries of the cities can be used

${ }^{2}$ World Bank: https://data.worldbank.org.cn/indicator/SP.URB.TOTL.IN.ZS?locations=XU 
to develop science and technology. Efficiency promotes the acceleration of agricultural development, which plays an important role in the development of the agricultural industry in Africa.

\subsection{Reasons for the Problems of Agricultural and Rural Development in Africa}

\subsubsection{The Proportion of Agricultural Mechanization Production Is Relatively Low}

The proportion of agricultural mechanization production in Africa is relatively low, which leads to a long-term low efficiency of local agricultural production. With the development of global science and technology, the cost of agricultural import and export trade in Africa will be higher than the international market, which will have a negative effect on African agricultural development. Agricultural development in Africa should actively use science and technology to improve efficiency, and at the same time actively use machinery and equipment to reduce product costs, which will have a positive effect on the speed of economic development in rural areas.

\subsubsection{The Speed of Industrial Transformation Is Not Fast Enough} In the long run, industrial transformation will greatly promote the improvement of agricultural production. Therefore, long-term agricultural development in Africa should be carried out by promoting local industrial transformation. Only by promoting the economy to the secondary and tertiary industries through industrial transformation, can the development of the technology industry be used to promote the faster development of agriculture. The development of the primary industry in Africa should be transformed to the secondary industry, which can lay the foundation for the efficient development of the primary industry in the future.

\subsubsection{The Government's Policies Are Not Scientific Enough}

The government's macroeconomic decision-making provides great help for agricultural and rural development, so it is difficult for some inefficient government policies in Africa to promote local economic development. Only by using more efficient economic development strategies can the development efficiency of the African region be improved. In the long run, the government's fiscal and monetary policies can drive the development of the technology industry, which is an important driving force for economic and industrial development.

\section{Policy Recommendations for Agricultural and Rural Development in Africa}

\subsection{Promote the Increase in the Proportion of Agricultural Mechanized Production}

The African region should promote agricultural mechanized production on a large scale. Through agricultural mechanized production, the efficiency of agri- 
cultural development in Africa can be improved, the economic development level of rural areas can be improved, and the living standards of local people can be improved. In the long-term economic development process, developed countries use mechanization to cover almost all their agricultural production. The technological and economic development disadvantages in Africa have hindered the development of local mechanized production. African governments should actively promote agricultural mechanized production and use China's "One Belt, One Road" initiative to improve the level of infrastructure construction and improve the efficiency of agricultural development.

\subsection{Promote the Acceleration of Industrial Transformation}

Industrial transformation in Africa also plays an important role in the development of the primary industry. The active transformation of the primary industry to the secondary industry can effectively improve the local economic development speed and promote the development of the technology industry. Agricultural production is a relatively primitive mode of economic development. Promoting the development of the agricultural industry through a good technology industry can better improve the efficiency of agricultural development. Industrial transformation has a positive role in promoting agricultural development in the long run, and the government should actively promote industrial transformation to provide assistance for agricultural and rural development.

\subsection{Hiring Think Tanks to Use Science for Macroeconomic Development Policy}

African governments can use local think tanks to help governments make science-based decisions. The government's monetary policy and fiscal policy can effectively improve short-term economic development. Local long-term economic development needs to drive the improvement of production efficiency through technological innovation, which is the core economic development method for the African region. African governments can use the cooperation of colleges and universities to improve the strength of talent training, and promote the scientific nature of government decision-making by cultivating think tanks for economic development, which will play a certain role in the long-term agricultural and rural development in Africa.

\section{Summary}

This paper expounds on the problems and countermeasures in the development of agriculture and rural areas in Africa through qualitative analysis. First, the current situation of agricultural and rural development in Africa is analyzed through three parts: the development of African agricultural trade import and export, the development of agricultural added value in Africa, and the environmental development of rural areas in Africa. Analyze and explain. Then, the problems existing in the development of agriculture and rural areas in Africa are ex- 
pounded in three parts: the relatively slow development of agricultural import and export trade volume, the relatively lagging overall economic development, and the low speed of urbanization; low, the speed of industrial transformation is not fast enough, and the government's policies are not scientific enough. The three parts are the reasons for the problems of agricultural and rural development in Africa. Finally, it proposes targeted policy recommendations for agricultural and rural development in Africa by promoting the proportion of agricultural mechanization production, promoting the acceleration of industrial transformation, and employing think tanks to use scientific macroeconomic development policies.

In the research process of this thesis, due to the limited ability to obtain relevant data, and because the cognition and knowledge reserves still need to be strengthened, there will be some omissions in the analysis process. Research in related fields to improve the ability to understand and advise on agricultural development in Africa.

\section{Conflicts of Interest}

The author declares no conflicts of interest regarding the publication of this paper.

\section{References}

Boahene, K. (2015). The Challenge of Deforestation in Tropical Africa: Reflections on Its Principal Causes, Consequences and Solutions. Land Degradation \& Development, 9, 247-258 https://doi.org/10.1002/(SICI)1099-145X(199805/06)9:3<247::AID-LDR278>3.0.CO;2-G

Davis, B., Giuseppe, S. D., \& Zezza, A. (2017). Are African Households (Not) Leaving Agriculture? Patterns of Households' Income Sources in Rural Sub-Saharan Africa. Food Policy, 67, 153-174. https://doi.org/10.1016/j.foodpol.2016.09.018

Dawson, N., Martin, A., \& Sikor, T. (2015). Green Revolution in Sub-Saharan Africa: Implications of Imposed Innovation for the Wellbeing of Rural Smallholders. World Development, 78, 204-218. https://doi.org/10.1016/j.worlddev.2015.10.008

Iwelunmor, J., Blackstone, S., Veira, D., et al. (2016). Toward the Sustainability of Health Interventions Implemented in Sub-Saharan Africa: A Systematic Review and Conceptual Framework. Implementation Science, 11, Article No. 43. https://doi.org/10.1186/s13012-016-0392-8

Carter, M. R., Cheng, L., \& Sarris, A. (2016). Where and How Index Insurance Can Boost the Adoption of Improved Agricultural Technologies. Journal of Development Economics, 118, 59-71. https://doi.org/10.1016/j.jdeveco.2015.08.008

Nagler, P., \& Naudé, W. (2017). Non-Farm Entrepreneurship in Rural Sub-Saharan Africa: New Empirical Evidence. Food Policy, 67, 175-191.

https://doi.org/10.1016/j.foodpol.2016.09.019

Schut, M., Rodenburg, J., Klerkx, L., Kayeke, J., Ast, A. V., \& Bastiaans, L. (2015). Raais: Rapid Appraisal of Agricultural Innovation Systems (Part ii). Integrated Analysis of Parasitic Weed Problems in Rice in Tanzania. Agricultural Systems, 132, 12-24. https://doi.org/10.1016/j.agsy.2014.09.004 
Valipour, M. (2015). Land Use Policy and Agricultural Water Management of the Previous Half of Century in Africa. Applied Water Science, 5, 367-395.

https://doi.org/10.1007/s13201-014-0199-1 